\title{
Factors Behind the Unrelenting Perseverance of the Minorities at the Marginal Status at Wolaitta Zone, Southern Ethiopia
}

\author{
Akalework Mengesha(Assistant professor of Sociology) \\ Woliatta Sodo University, Ethiopia \\ doi: 10.19044/esj.2017.v13n26p306 URL:http://dx.doi.org/10.19044/esj.2017.v13n26p306
}

\begin{abstract}
This article has managed to critically assess factors behind the unrelenting perseverance of the minorities at the margin of marginal status at Wolaitta zone, Southern Ethiopia. The study identifies basically the validation behind the persisted disadvantaged position of the occupational minorities that is embedded within the socio-cultural scenery of Woliatta. It has attempted to explain the marginal status of the occupational minorities in the face of altering socio-economic and political state of contemporary society.

A cross sectional qualitative method was used (in-depth interviews and focus group discussions) involving a total of 42 in-depth interview informants, 5 focus group discussions constituting 7 individuals in each group carried out in purposively selected sites.

It has been discovered that there are certain sections of society that are considered to be of lower status and thus, marginalized and excluded from the host community. The minority groups that occupy the subordinate stratum include Hilancha-craft workers and 'Ayille'social groups. These sections of the society have made to occupy the perimeter in essential societal activities and institutions. In other words, it's been branded that occupational groups are at the verge of social, economic and political spheres of the mainstream society. They are detested and relegated in all aspects of their life.
\end{abstract}

Keywords: Segregation, occupational minorities and majority

\section{Introduction}

In the history of human society, it is plainly apparent that there has been way of sorting out people to a meticulous group by appending to a kind of special attributes. As Dunn (2010) explains, such categorizing process takes its line which consists of socio-economic status of the individual or the 
group, ethnic or race background, gender, occupation, religion and disability of any nature. It is based on such distinctiveness that people are drawn to a certain category which determines their location in the societal ladder of stratification.

Having pre-eminence, which accounts to the cited indicators that the society utters, implies a superior position which grants others to be an entity of domination and exclusion. Thus, here comes the contemplation of marginalization which emerges out of the process. In other words, the hierarchical arrangement of society accompanies itself with wide-ranging facet of marginalization which is articulated in organizational endeavors that took place at societal level.

With the exception of its differing roots and scenery it takes, the very actof stratifying people is undoubtedly the fact of contemporary as well as traditional societies albeit itwas insignificant in earlier times.

In retort to this, modern societies has been unswerving a growing attempt to incorporate the marginalized and underprivileged groups of people in to the mainstream society by giving due prominence to economic and socialinequality. Nonetheless, the social and economic integration of minorities is still foremost political, societal and economic challenge.

The relegated stipulation of these groups is not a restricted phenomenon rather it occurs in different corner of the country both in past and present. Among these communities where one canuncovermassive inequality and marginalization of such groups, the Woliatta society is the mostconspicuous societies. In the social hierarchy of Woliatta, the 'Qomo' or the 'Goqqas' occupy the upper status and comprises the majority of the population (Haileyesus 1996, cited in Akalework, 2011). Whereas, the minority groupsthat occupy the lower strata include artisans and the so called 'Ayilles'. Hence, this study is concerned to resolutely assess the factors behind the inexorable perseverance of the minorities at the margin of societal endeavors at Wolaitta zone, Southern Ethiopia.

\section{Research methods}

\section{Theoretical model}

In this research article assumes the theoretical conjecture of internal specialization model in explaining the emergence of marginalized minority groups. The model emphasis on internal occupational differentiations and specialization within certain population. It claims that differentiation and specialization results in the emergence of ruling elites and hierarchical division of classes which in turn basis for the formation of marginalized minority groups It argues that internal specialization and differentiation within a given society results in occupational differences and specialization in certain activities among the members and the emergence of dominant 
majority and dominated occupational minorities. (Freeman, 2001). Hence, this study goes along with the arguments of internal specialization model in understanding the conditions of occupational group since the emergence of the group has been tied with nature of their occupation.

In order to meet the objectives stated, in simple terms, the study has drawn on qualitative research methods. The study employed qualitative research methods with the aim of gathering information on various factors that made the minority group to be located at the edge societal endeavors. Hence, the crucial body of a cross sectional qualitative information was gained through in-depth interviews and Focus Group Discussions (FGDs) which were guided by semi-structured interviews. A total of 42 in-depth interview informants, 5 focus group discussions constituting 7 individuals in each group carried out in purposively selected sites.

The interviews were carried out using the local language, Wolaitigna. All interviews were taped with the acquiescence of informants..

\section{Results and discussion}

The factors that contributed for the marginalization and relegation of the occupational minorities have been presented in line with each of the groups found in the study area.

\subsection{The 'Chinasha'(Potters)}

These are mainly marginalized and detestable section of society in Woliatta. It is far and widely held view that the potters are sternly disregarded and despised categories among the occupational minorities. This is basically due to three significant allegations, among others, by the larger community.

\subsubsection{The notion of impurity}

The first assertion held by the farmer community as validation for their marginalization is the conception of impurity. The mainstream community is certain that the potters are impure due to their consumption habits citing the fact that they eat meat of animalsthat have not been ritualistically and applicably slaughtered. It is ordinarily accepted that potters, since unknown time till present, have the habit of eating dead animals which is wicked and deemed intolerable in view of both the cultural values and religiousstance of the majority. The FGD participant from the farming population presents his outlook in his own words as:

"It is indisputable that these people are doing something disgraceful to us till today. They eat everything I can say our community sturdily discards, considers dissolute and sinful. Even today they are doing same thing their forefathers had been practicing. We 
always caught those eating deceased animals behind their closed doors and yet they seem to deny this fact. What amazes me most is that being converted to Christian didn't leave off them from doing this evil habit. I think I, for my part, accept as true that there resides a pitiless spirit passing from one generation to next"

On the other hand, the potter community to certain extent rejects the allegation. They appear to concede the fact that their forefathers had been eating dead animals in certain occasions. However, such habits are come to the limit of purge. A 55 year old potter woman states,

"Though I have witnessed such habits in early times, I can safely say that it's been thrown away. I am a Christian woman and believe in Jesus as personal savior, thus I utterly cast-off contentions like that by the mainstream community. I can assure you that no one in our village eating dead animals at present time. As you said I listen to gossips spreading out, at times, that Mr. X has been caught eating dead animals nevertheless no one has determinedthe evidence. In my view I think they are trying to substantiate their unfounded act of mortifying and segregation."

The most central point is that this notion of impurity has a colossal effect in distressing the lives of potters and playing its part for their outranked location in society.

\subsubsection{The belief of 'Evil eye' possession}

This is very momentous allegation by farming population is the belief of the so-called 'Evil eye' possession-locally called 'Goromote Ayana'. As it has been identified from the data, there is principally held belief within the mainstream community that potters are with the supreme punishing and perilous evil spirit on their eyes bring about the death of many people in village irrespective of one's age, sex, and social class. The village community counts the cost this evil spirit on their eyes has brought to their children and neighborhood. Many members of the community, from the children to elderly, have been passed away not exactly knowing the cause, from the medical point of view. It's been also pointed out that the farming population knows the warning signs when one is possessed with evil spirit. As result, they vehemently probe the person who believed to be accountable inproducing the spirit to spit on sick individual. If that does not work, they may go to a level of killing alleged evil eye possessor. A 68 year old man at Damot Gale Woreda described his observation as follows:

"...I do not want to hark back to all those hideous things these evil people done to our community. It is very horrible to lose your lovely teenagers and loved once out of the blue and having no time for you to take care of them even when they are sick. I have seen in 
my age so many children died very soon as we make out they are sick. It seems that the spirit gives you no time to deal with it. In some cases, people bring the sick person as quick as possible to the evil eye possessor and get healed. Conversely, the matter of fact is that such instances are thoroughly infrequent. In reaction to situation like these, we take grave move to destroy their property and lives as well......"

The majority-the 'Goqqa' population, by and large, established the belief that potters are the one accountable for mysterious death of people in the village. Because of such conviction, the farming population took various way outs. They knowingly take raid on the pottery products, house and killing them (more common in early time). Such break-ins are most of time taken at night time and accidental for potter community, which makes them more vulnerable. The researchers have seen possibly such an attack at the first round of data collection in Damot Gale Woreda, Gacheno area. The youngstersfrom the farming populations every now then, when they pass by, destroy their property, most notably attack house with rock-strewn. The picture below shows pelting of potter house at the night before the picture taken in pre-lunch.

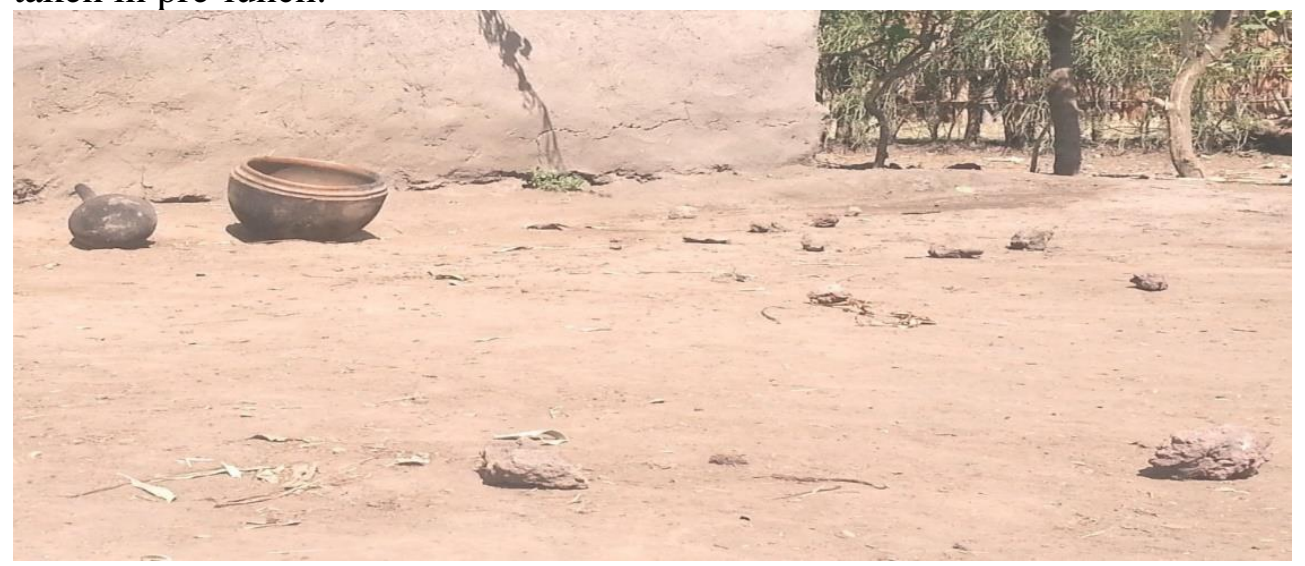

It's been found that this is the least possible type of attacks taken against the potter community and it happens so recurrently. Apart from such moves, the mainstream community relies on religious practices of expelling the evil spirit after once possessed with the spirit. There is also a habit portrayed by the Goqqa teenagers and youth when they cross the potter houses. They, on purpose, nibble their forefinger as soon as they see a person from potter community with trust that it helps to shield oneself from the evil spirit. The potter community member also displays alike reaction to send a message that they are not 'Gormote'-Evil eye possessor.

On the contrary, the potters absolutely throw away such allegation and they assume that it is not something exclusively characterizes them. It is 
marked that there are individuals from both the farming population and the potter category whom the communities recognize as Evil eye possessor. In other words, it has been discovered that it is easy for any interested person to identify the so called Evil spirit possessor both from the 'Goqqa' majority as well as the potter social group. In consequence, the assertion that potters have a distinctive feature of the Evil-eye possession is not acceptable since it is common to see individuals from farming population having such contentions. However, considering their small population size, the degree of being regarded in that way will be more undoubted besides their defenseless circumstances. It is very common for the potter community member to be labeled as 'Goromote'. Thus, become targets of demolition of property, segregation, and murder. They are left vulnerable to the extent that the local Keble administration is unwilling to take legal reproof when they bring various cases of raids and assault. This is due to the fact the kebele administration unable to go against well established hostile attitude towards potters. They are also victim of this attitudinal boundary.

Though the qualitative data indicated that much attention has not been given by the government and different stakeholders in general, slender change begun with the coming of 1974 revolution. Some sorts of changes come into sight as a result of the government by securing small plot of land ownership. Moreover, as outlined by informants, these occupational groups had also the scene to partake in different village level associations, which are till minimal.

In the advent of the existing government, the situation of occupational groups can be examined from the direction of incongruity and extremities. This is to imply the fact that they are uncovered to severe biases and right flouting at the same time as exemplified by enhanced membership and attachment in some way. Moreover, they insisted that the policy of the current government seems to be feeble in retaining social equality at the lower levels. The minorities in some instances are stripped to severe exploitation and domination, as it was in the earlier periods, by the dominant groups as a result of their life threatening economic situation and interrelated stereotyped image of them.

On contrary point of view, they recognized the changes observed due to the spread of Protestant religion despite the fact that there is a kind of impasse apparent in varying contexts as to the complete integration of them to the host society till today. This episode enabled them to play a part in various social activities and associations. The protestant churches claim all social groups in the same way. The preachers of the flock indict social discrimination between the minority and the dominant Goqqa groups. This progress not in favor of bigotry enthralled many people who started to unite the protestant churches. However, the intricate difficulty of prohibiting 
continued in the face of such changes particularly when it comes to daytoday social settings, martial affiliation between the minority and the dominant majorities since the churches have the role not more than preaching the equality and rights of the people in terms of religious justification. follows,

A 56 year old potter man states his experience in this regard as

"I don't know from where to begin. Let me tell the most common offence these people are committing on our community so persistently. The day before you come here, it is around 1 o'clock local time at night and I am drinking coffee with my family after work. Even we didn't bring our pottery products inside our home. As a usual, the youngsters they are coming from church, begun to toss stones of various size to our property, home and to us. We were shouting and nobody act in response from the 'Goqqa' community. The gloomiest part is that even our potter man and woman didn't help each other in such instants for the reason that we are anxious about the consequence. They smashed everything and injured some of us. We reported to the local Keble administration instantaneously yet they merely said they will see the case in tomorrow morning. They always try to play away us by saying they are going to take legal move but then again they never did. Obviously, we are downhearted and abandoned, it rightly distresses me inside."

\subsubsection{The nature of occupation of the minority groups}

The third important validation of the 'Goqqa' majority in segregating and relegating is highly related to the nature oftheir occupation. It is plain that the mainstream community's livelihood is based on farming and they depend on Agricultural production for their survival. On contrary, the potter population depends predominantly on pottery production as livelihood strategy since indefinite time. The dominant group explains that their status is divinely predestined and cursed to sub-human occupation of pottery.

\section{2'Degella'(Tanners)}

The essential validation for exclusion of tanners is for the most part tied to their occupation of tanning. The host society accepts as true that such occupation is degrading and unhygienic.

More to the point, societal unenthusiastic view of their occupation, the Goqqas' exclusion of tanners is essentially related to the accusation that they consume the left-over pieces or animal parts such as hooves, heads, 
intestines, which are not eaten by the larger society. In consequence, they are viewed as sub-humane and impure.

\subsection{Wogacciya( Smiths)}

The Smiths are also one of the marginalized and detested sections of the society the Wolaitta. The fundamental validation for the persisted segregation of group is highly tied to their occupation of smithing which the mainstream community considers it as humiliating and greatly undignified. In line with 43 year interviewee states his experience as follows;

"I have been smithing since my childhood. I inherited it from my father. I very much conceited of this occupation because it means everything to me. Though I do not think that it is paying me back much, it is prime source of income and we are make a living out it. However, the people around us still show a sign of insolence and disregard just due to our occupation. "

Therefore, this is the lone factor that played a significant role in making them to occupy a very low position that persisted till today.

\section{Conclusion}

In this paper great deal effort has been made to examine various factors that made the segregation of the occupational minorities persistent. It has attempted to elucidate the disadvantaged status of the occupational minorities and inconsequential move on the part of state machinery as well as the various stakeholders is working to halt marginalization, discrimination of any kind.

The analysis has been largely emphasized on the situation of occupational minorities such as potters, Tanners and smiths.

And so, Potters arepositioned at the bottom in the stratification hierarchy and kept secluded from farmer community, lacking their privileges.the most important validation for their degrading situation is related to factors such as the notion of impurity, the belief of 'Evil Eye' possession and nature of their occupation. The essential source of exclusion of tanners is for the most part tied to their occupation of tanning. Due to such factors, restrictions and discrimination appear to be persistent and well established still today.

In general, it is well addressed that these occupational minorities are at verge of all important societal accomplishments and this is by extension flouting the advancement of Wolaitta society. 


\section{References:}

1. Chiatii, Remo. 1984. "The politics of Divine kingship in Wolaitta in $19^{\text {th }}$ and 20th centuries." Ph.D. Dissertation, University of Pennsylvania

2. Dunn, Ruth. 2010. Minority studies: A Brief Sociological Text. Connexious, Rice University, Texas

3. Freeman, Dena and Pankhurst Alula. 2001. Living on the Edge: Marginalized Minorities of craft workers and hunters in southern Ethiopia. Addis Ababa University

4. Grusky, David. 2001. Social Stratification: Class, Race, and Gender in Sociological perspective. $2^{\text {nd }}$ ed. West view press.

5. Haileyesus, Seba. 1996. "A study of Social change in Wolaitta, Southern Ethiopia." unpublished MA thesis, Department of Social Anthropology, Addis Ababa University

6. Harris, Marvin. 1975. Culture, People, Nature: An Introduction to General Anthropology. New York: Thomas Y.Crowell Company Inc.

7. Mullaly, B. 2007. "Oppression: The focus of structural social work." Pp.252-286 in B. Mullaly, The new structural social work. Don Mills: Oxford University Press.

8. Pankhurst, Alula. 2001. Dimensions and Conceptions of Marginalization' in Freeman Dena and Pankhurst, Alula(eds) Living on the Edge: Marginalized Minorities of craft workers and hunters in southern Ethiopia. Addis Ababa University

9. Schaefer, Richard T. 1993. Racial and Ethnic Groups. New York: Harper Collins College publishers

10. Vander, Zanden and Jamesh.1983.American Minority Relations. New York: Alfred Knopf.

11. Williams, Jr.Robbin. 1964. Strangers Next Door: Ethnic Relations in America. Infl communities. New Jersey: prentice- Hall Inc. 